\title{
Effect of dietary conjugated linoleic acid (CLA) on lipid composition, metabolism and gene expression in Atlantic salmon (Salmo salar) tissues.
}

\author{
Michael J. Leaver ${ }^{\mathrm{a}, *}$, Douglas R. Tocher ${ }^{\mathrm{a}}$, Alex Obach ${ }^{\mathrm{b}}$, Linda Jensen ${ }^{\mathrm{b}}$, R. James \\ Henderson $^{\mathrm{a}}$, Allan R. Porter ${ }^{\mathrm{a}}$ and Grigorios Krey ${ }^{\mathrm{c}}$ \\ ${ }^{a}$ Institute of Aquaculture, University of Stirling, Stirling FK9 4LA, UK \\ ${ }^{b}$ Nutreco Aquaculture Research Centre (ARC), P.O. Box 48, N-4001 Stavanger, Norway \\ ${ }^{c}$ National Agricultural Research Foundation-Fisheries Research Institution (NAGRF-FRI), GR- \\ 64007, Nea Peramos, Kavala, Greece
}

*, Correspondence to: Dr. M.J. Leaver, Institute of Aquaculture, University of Stirling, Stirling FK9 4LA, United Kingdom. Tel. No: +44 1786 467927; Fax No: +44 1786 472133; Email: m.j.leaver@stir.ac.uk

\begin{abstract}
Dietary conjugated linoleic acid (CLA) affects fat deposition and lipid metabolism in mammals, including livestock. To determine CLA effects in Atlantic salmon (Salmo salar), a major farmed fish species, fish were fed for 12 weeks on diets containing fish oil or fish oil with $2 \%$ and $4 \%$ CLA supplementation. Fatty acid composition of the tissues showed deposition of CLA with accumulation being 2 to 3 fold higher in muscle than in liver. CLA had no effect on feed conversion efficiency or growth of the fish but there was a decreased lipid content and increased protein content after 4\%CLA feeding. Thus, the protein:lipid ratio in whole fish was increased in fish fed 4\% CLA and triacylglycerol in liver was decreased. Liver $\beta$-oxidation was increased whilst both red muscle $\beta$-oxidation capacity and CPT1 activity was decreased by dietary CLA. Liver highly unsaturated fatty acid (HUFA) biosynthetic capacity was increased and the relative proportion of liver HUFA was marginally increased in salmon fed CLA. CLA had no effect on fatty acid $\Delta 6$ desaturase mRNA expression, but fatty acid elongase mRNA was increased in liver and intestine. In addition, the relative compositions of unsaturated and monounsaturated fatty acids changed after CLA feeding. CLA had no effect on PPAR $\alpha$ or PPAR $\gamma$ expression in liver or intestine, although PPAR $\beta 2 \mathrm{~A}$ expression was reduced in liver at 4\% CLA feeding. CLA did not affect hepatic malic enzyme activity. Thus, overall, the effect of dietary CLA was to increase $\beta$ oxidation in liver, to reduce levels of total body lipid and liver triacylglycerol, and to affect liver fatty acid composition, with increased elongase expression and HUFA biosynthetic capacity.
\end{abstract}

Keywords: CLA, PPAR; $\beta$-oxidation; fatty acid; desaturation; elongation; Atlantic salmon. 


\section{Introduction}

Conjugated linoleic acid (CLA) is a term used to describe positional and geometric isomers of linoleic acid (18:2n-6; LA), the two main naturally occurring isomers being cis-9,trans-11 and trans-10,cis-12. These compounds occur particularly in beef and dairy products but are widespread at lower levels in many foodstuffs (Chin et al., 1992, Pariza et al., 2001). Dietary inclusion of CLA can cause significant alterations in energy and lipid metabolism in mammals leading to reductions in overall body fat mass. This has been suggested to be a positive effect in a variety of farmed species and animal disease models and by extension, humans (Belury, 2002; Thiel-Cooper et al., 2001, Wang and Jones, 2004). However, there are notable species differences in the tissue-specific pattern of effects caused by CLA. For example feeding CLA can be accompanied by accumulation of lipid in mouse liver and the development of lipodystrophy and insulin resistance (Tsuboyama-Kasaoka et al., 2000, Clement et al., 2002), whereas these deleterious effects are not observed in hamster, Mesocricetus auratus (Bouthegourd et al., 2002, Macarulla et al, 2005). CLA has also been shown to alter highly unsaturated fatty acid (HUFA) biosynthesis in cellular models (Chuang et al, 2001a, b; Eder at al., 2001), and to increase expression of genes involved in the HUFA biosynthetic pathway (Takahashi et al., 2003). The mechanisms of action of CLA in mammals are unclear, and few studies on CLA in nonmammalian species have been undertaken. However, the effects induced by CLA feeding on mammalian fat deposition and HUFA biosynthesis may be of considerable interest to the finfish aquaculture industry. This is because current practise in aquaculture, and particularly Atlantic salmon aquaculture, can lead to excess deposition of fat in the muscle of farmed fish (Sargent et al., 2002). In addition, the global limit on the supply of fish oil (Naylor et al., 2000) is driving the replacement of fish oils with plant-derived oils in aquaculture diets (Bell et al., 2005). This has raised concern regarding the potential for reducing levels of human health-promoting n-3 HUFA in farmed fish (Sargent and Tacon, 1999). The aim of the present study is to investigate the effects of dietary CLA on lipid metabolism, HUFA biosynthesis and lipid composition in the liver and muscle of Atlantic salmon (Salmo salar). The results are discussed in relation to observations in mammals and with regard to the potential use of CLA in aquaculture diets.

\section{Materials and methods}

\section{Fish and Diets}

Three diets (4 mm pellets) containing CLA at inclusion levels of 0, 2 and 4\% were prepared at the Nutreco Technology Centre, Stavanger, Norway. The diets were formulated to satisfy the nutritional requirements of salmonid fish (U.S. National Research Council 1993), and had the same basal composition containing 47\% protein and 33\% lipid, consisting of fish meal (55\%), corn gluten (10\%), wheat (8.3\%), oil (26.3\%), mineral and vitamin mixes $(0.2 \%)$ and carophyl pink ${ }^{\circledR}(0.06 \%)$. The oils used were fish oil (Anchovy oil, Skretting, Stavanger, Norway), either alone or in combination with CLA (Tonalin ${ }^{\circledR}$ FFA80, containing 81\% CLA free fatty acid as a 50:50 mixture of cis9, trans11 and trans10, cis12 isomers; Natural ASA, Sandvika, Norway) which replaced fish oil to the level of $2 \%$ and $4 \%$ of the total diet. The fatty acid compositions of the experimental diets are given in Table 1. Seven hundred and fifty Atlantic salmon postsmolts, average mass 132g, were distributed randomly into three 2 x $2 \mathrm{~m}$ tanks (250/tank) at the Nutreco Aquaculture Research Centre, Lerang Research Station, Stavanger, Norway. Twenty fish per tank were PIT-tagged by implanting a micro-transponder into the peritoneal cavity. The fish were adapted to the new environment for 3 weeks before feeding the experimental diets. During the adaptation period, the fish received commercial diet (Atlantic 4mm; Skretting). Feed intake 
Table 1

Fatty acid compositions (percentage of weight) of experimental diets

\begin{tabular}{|c|c|c|c|}
\hline & Fish oil & $2 \%$ CLA & $4 \%$ CLA \\
\hline $14: 0$ & 7.4 & 6.9 & 6.5 \\
\hline $16: 0$ & 18.7 & 17.7 & 16.9 \\
\hline $18: 0$ & 3.9 & 4.0 & 4.0 \\
\hline Total saturated ${ }^{1}$ & 30.9 & 29.3 & 28.0 \\
\hline $16: 1 n-7$ & 7.5 & 7.1 & 6.4 \\
\hline $18: 1 n-9$ & 8.8 & 9.5 & 10.0 \\
\hline $18: 1 n-7$ & 2.7 & 2.7 & 2.6 \\
\hline $20: 1^{2}$ & 3.3 & 2.7 & 2.7 \\
\hline $22: 1^{3}$ & 3.5 & 2.9 & 2.9 \\
\hline $24: 1 n-9$ & 0.5 & 0.6 & 0.5 \\
\hline Total monoenes & 26.3 & 25.5 & 25.1 \\
\hline $18: 2 n-6$ & 3.5 & 3.8 & 3.7 \\
\hline CLA (9c,11t) & 0.0 & 1.9 & 4.6 \\
\hline CLA (10t,12c) & 0.0 & 1.9 & 4.5 \\
\hline $20: 4 n-6$ & 0.9 & 0.9 & 0.8 \\
\hline Total n-6PUFA ${ }^{4}$ & 4.7 & 8.8 & 13.9 \\
\hline $18: 3 n-3$ & 1.2 & 1.2 & 1.1 \\
\hline $18: 4 n-3$ & 3.4 & 3.1 & 2.9 \\
\hline $20: 4 n-3$ & 0.8 & 0.8 & 0.7 \\
\hline $20: 5 n-3$ & 14.7 & 13.8 & 12.5 \\
\hline $22: 5 n-3$ & 1.7 & 1.6 & 1.4 \\
\hline $22: 6 n-3$ & 16.3 & 15.9 & 14.4 \\
\hline Total n-3PUFA & 38.1 & 36.4 & 33.0 \\
\hline Total PUFA & 42.8 & 45.2 & 46.9 \\
\hline
\end{tabular}

Data are means of analyses of two samples, each of which contained pellets pooled from three bags. Variation between the duplicate pools was less than 5\%. ${ }^{1}$, contains 15:0 and 17:0, present in some samples at up to $0.5 \%$;

2, predominantly n-9 isomer; ${ }^{3}$, predominantly n-11 isomer; ${ }^{4}$, totals include $20: 2 \mathrm{n}-6$ present at up to $0.3 \%$. CLA, conjugated linoleic acid; PUFA, polyunsaturated fatty acid.

was monitored during this period, and the trial did not start until appetite was at least $0.8 \%$ body weight. After the adaptation period, the fish were fed the experimental diets to satiation according to usual procedures at Lerang Research Station, for a period of 4 months. Feed intake was monitored throughout the trial and waste feed was collected from the effluent water from each tank by a wire mesh collector and dried. Feed given, waste feed and the resulting net feed intake were registered daily. Any mortalities were collected daily. The tanks were supplied with sea water at constant temperature $\left(7.9{ }^{\circ} \mathrm{C} \pm 0.1{ }^{\circ} \mathrm{C}\right)$. The oxygen level varied between 8 and 12 ppm, with an average of $9.9 \mathrm{ppm}$. A photoperiod of $18 \mathrm{~h}$ light and $6 \mathrm{~h}$ darkness was applied.

\section{Sampling protocols}


At the start and end of the trial, all the fish in each tank were anaesthetised with metacain $(50 \mathrm{mg} / \mathrm{L})$, individually weighed and measured. At the end of the trial, 20 fish per dietary treatment were sampled for compositional, enzymatic and molecular analyses, with 3 whole fish frozen immediately on dry ice and subsequently stored at $-20{ }^{\circ} \mathrm{C}$ for whole body compositional (proximate) analyses. The other sampled fish were eviscerated and twelve used for biometric determinations (hepato-, viscero- and gonado-somatic index) and for lipid analyses. Muscle samples (Norwegian quality cut) and livers were taken from each fish, pooled in four pools of 3 fish each, and frozen immediately in liquid nitrogen (livers) or dry ice (muscle). Samples of liver, white muscle (WM), red muscle (RM) and intestine were dissected from the remaining 5 fish for molecular and biochemical analyses. Specifically, samples of $0.5 \mathrm{~g}$ of liver and intestine (pyloric caeca) were rapidly dissected into $5 \mathrm{ml}$ of TriReagent (Sigma, Poole, UK) and immediately homogenised using an Ultra-Turrax tissue disrupter (Fisher Scientific, Loughborough, U.K.), and then frozen in liquid nitrogen for RNA analyses. In addition, samples of 1-2g of liver, WM and RM for biochemical analyses were immediately frozen in liquid nitrogen. All samples for molecular and biochemical studies were subsequently stored at $-80{ }^{\circ} \mathrm{C}$.

\section{Proximate analyses (whole body moisture, lipid, protein and ash determinations}

Moisture content of whole fish was determined after drying in an oven at $80{ }^{0} \mathrm{C}$ for a minimum of $72 \mathrm{~h}$. The dried fish samples were then rigorously blended into a homogeneous crumble/meal and used for determination of whole body lipid, protein and ash contents. Lipid content in $1 \mathrm{~g}$ samples of dried fish crumb was determined using the Soxhlet method with extraction in petroleum ether at $120{ }^{\circ} \mathrm{C}$ (Avanti Soxtec 2050 Auto Extraction apparatus; Foss, Warrington, UK). Protein content $(\mathrm{N} \times$ 6.25) was determined in the fish crumble using the automated Kjeldahl method (Tecator Kjeltec Auto 1030 Analyser; Foss, Warrington, UK). Ash contents were determined after heating portions of the fish crumble at $160{ }^{\circ} \mathrm{C}$ for $48 \mathrm{~h}$.

\section{Lipid analyses}

Liver and skinned and deboned muscle samples, each consisting of three fish, were homogenised into pooled "pates". Total lipid was extracted from diets or 1 g portions of tissue pates by homogenising in $20 \mathrm{vol}$ of chloroform/methanol (2:1, v/v) in an Ultra-Turrax tissue disrupter (Fisher Scientific, Loughborough, U.K.). Total lipid was prepared according to the method of Folch et al. (1957) and non-lipid impurities removed by washing with $0.88 \%$ (w/v) $\mathrm{KCl}$. The weight of lipid was determined gravimetrically after evaporation of solvent and overnight desiccation in vacuo.

Separation of lipid classes was performed by high-performance thin-layer chromatography (HPTLC). Approximately $10 \mu \mathrm{g}$ of total lipid was applied as $2 \mathrm{~mm}$ streaks and the plate

developed to two-thirds distance with methyl acetate/isopropanol/ chloroform/methanol/0.25 \% aqueous $\mathrm{KCl}$ (25:25:25:10:9, by vol.). After desiccation, the plate was fully developed with isohexane/diethyl ether/acetic acid (85:15:1, by vol.). The lipid classes were quantified by charring at $160{ }^{\circ} \mathrm{C}$ for 15 min after spraying with $3 \%(\mathrm{w} / \mathrm{v})$ aqueous cupric acetate containing 8 $\%$ (v/v) phosphoric acid, followed by densitometry using a Shimadzu CS-9000 dual-wavelength flying spot scanner and DR-13 recorder (Henderson and Tocher 1992).

Fatty acid methyl esters (FAME) from diets and tissue total lipid were prepared by acidcatalysed transesterification of total lipid according to the method of Christie (1982). Extraction and purification of FAME was performed as described by Tocher and Harvie (1988). FAME were separated and quantified by gas-liquid chromatography (Carlo Erba Vega 8160, Milan, 
Italy) using a 30m x $0.32 \mathrm{~mm}$ i.d. capillary column (CP Wax 52CB, Chrompak, London, U.K.) and on-column injection. Hydrogen was used as carrier gas and temperature programming was from $50^{\circ} \mathrm{C}$ to $150^{\circ} \mathrm{C}$ at $40^{\circ} \mathrm{C} \mathrm{min}{ }^{-1}$ and then to $230^{\circ} \mathrm{C}$ at $2.0^{\circ} \mathrm{C} \mathrm{min}^{-1}$. Individual methyl esters were identified by comparison with known standards and by reference to published data (Ackman 1980; Tocher and Harvie 1988). Data were collected and processed using the Chromcard for Windows (version 1.19) computer package (Thermoquest Italia S.p.A., Milan, Italy).

\section{Northern analyses}

Northern analysis was used to determine the expression of a variety of genes including the PPAR subtypes (PPAR $\alpha$, PPAR $\beta 1$, PPAR $\beta 2$ and PPAR $\gamma$ : (EMBL acc nos AM230809, AJ416953, AM229306, AJ416951) and selected target genes including fatty acid $\Delta 6$ desaturase and elongase (Zheng et al., 2005, Acc N. AJ458652), and CPTI (Acc No. AM230810) These were carried out by hybridising blots consisting of RNAs from liver or intestine from each of four fish fed the different dietary treatments. For the PPARs blots were probed with ${ }^{32} \mathrm{P}$-labelled cDNAs corresponding to the ligand-binding domains of each subtype. For the $\Delta 6$ desaturase and elongase the entire coding regions were used as probes and for carnitine palmitoyl acyltransferase (CPT1) a partial cDNA was utilised. A salmon cDNA for glyceraldehyde phosphate dehydrogenase (GAPDH; Acc no. AM230811) was used as a control. After autoradiography, hybridising material was quantified using the Total-Lab software package (Phoretix) and for each gene the results were normalised to GAPDH signal.

\section{Fatty acid desaturation and elongation (HUFA synthesis) in liver microsomes.}

Portions of frozen liver were weighed and homogenised to $10 \%(\mathrm{w} / \mathrm{v})$ in $0.25 \mathrm{M}$ sucrose in 40 $\mathrm{mM}$ phosphate buffer $\mathrm{pH} 7.4$ containing $1 \mathrm{mM}$ EDTA, $0.15 \mathrm{M} \mathrm{KCl}, 40 \mathrm{mM} \mathrm{KF}$ and $1 \mathrm{mM} \mathrm{N}-$ acetyl cysteine. The homogenate was centrifuged at $25000 \mathrm{~g}$ for $15 \mathrm{~min}$ at $4{ }^{\circ} \mathrm{C}$, the floating fat layer removed by aspiration and the remaining supernatant centrifuged at $105000 \mathrm{~g}$ for $60 \mathrm{~min}$ at $4{ }^{\circ} \mathrm{C}$. The floating fat layer was aspirated and the supernatant decanted. The pelleted microsomal fraction was resuspended in $1 \mathrm{~mL}$ of sucrose buffer and $50 \mu \mathrm{L}$ taken for protein determination according to Lowry et al (1951) after incubation with $0.45 \mathrm{~mL}$ of $0.25 \%$ (w/v) SDS/1M NaOH for $45 \mathrm{~min}$ at $60^{\circ} \mathrm{C}$.

The assay mixture, in sucrose buffer $\mathrm{pH} 7.4$, contained $5 \mathrm{mM} \mathrm{MgCl}_{2}, 1.5 \mathrm{mM}$ glutathione, $0.5 \mathrm{mM}$ nicotinamide, $1 \mathrm{mM} \mathrm{NADH}, 100 \mu \mathrm{M}$ coenzyme A, and $5 \mathrm{mM}$ ATP in a total volume of $0.75 \mathrm{ml}$. Fifty $\mu \mathrm{L}$ of $\left[1-{ }^{14} \mathrm{C}\right] 18: 3 \mathrm{n}-3(0.25 \mu \mathrm{Ci}, 5 \mu \mathrm{M}$ final concentration), as a fatty acid-free bovine serum albumin (FAF-BSA) complex (Ghioni et al., 1997), was added and the reaction initiated by the addition of $200 \mu \mathrm{L}$ (4-6mg microsomal protein) of microsomes. Incubation continued for $1 \mathrm{~h}$ at $20{ }^{\circ} \mathrm{C}$ and the reaction was stopped by the addition of $5 \mathrm{~mL}$ of chloroform/methanol (2:1, v/v) containing $0.01 \%$ BHT. Total lipid was extracted, transmethylated and FAME prepared as described above. The methyl esters were redissolved in $100 \mu \mathrm{L}$ isohexane containing $0.01 \%$ BHT and applied as $2.5 \mathrm{~cm}$ streaks to thin-layer chromatography (TLC) plates impregnated by spraying with 2 g silver nitrate in $20 \mathrm{~mL}$ acetonitrile and pre-activated at $110{ }^{\circ} \mathrm{C}$ for $30 \mathrm{~min}$. Plates were fully developed in toluene/acetonitrile (95:5, v/v) (Wilson and Sargent, 1992). Autoradiography was performed with Kodak MR2 film for 6 days at room temperature. Areas of silica containing individual fatty acids were scraped into scintillation mini-vials containing $2.5 \mathrm{~mL}$ of scintillation fluid (Ecoscint A, National Diagnostics, Atlanta, Georgia) and radioactivity determined in a TRI-CARB 2000CA 
scintillation counter (United Technologies Packard, U.K.). Results were corrected for counting efficiency and quenching of ${ }^{14} \mathrm{C}$ under exactly these conditions.

Assay of malic enzyme (ME), carnitine palmitoyl acyltransferase 1 (CPT1) and fatty acyl $\beta$ oxidation.

Liver, red and white muscle were weighed, diced and homogenised to $20 \%$ (w/v) in $0.25 \mathrm{M}$ sucrose in $10 \mathrm{mM}$ N-2-hydroxyethylpiperazine-N'-2-ethanesulfonic acid (HEPES) buffer and 1 $\mathrm{mM}$ EDTA, $\mathrm{pH}$ 7.4. The homogenates were centrifuged at $1880 \mathrm{x} \mathrm{g}$ for $10 \mathrm{~min}$ at $4^{\circ} \mathrm{C}$, the floating fat layer aspirated and the post-nuclear fractions (supernatant) collected, $50 \mu \mathrm{L}$ taken for protein determination as above, and portions used immediately for determination of enzyme activities.

For ME, each assay consisted of $100 \mathrm{mM}$ Tris/HCl buffer (pH 7.4), $0.5 \mathrm{mM} \mathrm{MnCl} 2,0.34$ $\mathrm{mM} \mathrm{NADP}^{+}$, and 10-100 $\mu \mathrm{g}$ of homogenate protein in a total volume of $195 \mu \mathrm{L}$. The reaction was initiated by the addition of L-malate to $0.5 \mathrm{mM}$ and the time course of NADPH production at $20^{\circ} \mathrm{C}$ was monitored spectrophotometrically at $340 \mathrm{~nm}$. Controls consisted of identical reactions without the addition of malate and resulting background rate from these blanks were subtracted from sample rates.

For CPT1, each reaction was run in a volume of $100 \mu \mathrm{L}$ at $20^{\circ} \mathrm{C}$ and consisted of $100 \mathrm{mM}$ Tris/HCl, pH7.4, 5 mg/ml FAF-BSA, 1mM DTT, 4mM MgCl $2,15 \mathrm{mM} \mathrm{KCl,} 1 \mathrm{mM} \mathrm{KCN,} \mathrm{2mM}$ carnitine, $1 \mu \mathrm{Ci}{ }^{3} \mathrm{H}$-carnitine $(1 \mu \mathrm{Ci} / \mu \mathrm{mol})$, and $10-100 \mu \mathrm{g}$ of homogenate protein. Reactions were initiated by the addition of palmitoyl-CoA to $100 \mu \mathrm{M}$. Controls consisted of identical reaction without palmitoyl-CoA. After $15 \mathrm{~min}$, the reactions were terminated by the addition of $60 \mu \mathrm{L}$ of $1 \mathrm{M} \mathrm{HCl}$ followed by the addition of $500 \mu \mathrm{L}$ of water saturated butanol. The samples were vigorously mixed for $30 \mathrm{~s}$, centrifuged to separate phases and $300 \mu \mathrm{L}$ of the upper butanol phase recovered. The recovered phase was back extracted by vigorously mixing with $1 \mathrm{~mL}$ of water for $30 \mathrm{~s}$ before repeating the centrifugation. One hundred $\mu \mathrm{l}$ of the upper butanol phase was transferred to a scintillation mini-vial and radioactivity determined as described above.

Total fatty acyl $\beta$-oxidation was assayed essentially as described previously (Torstensen et al., 2000). Briefly, the freshly prepared assay medium contained $13.2 \mathrm{mM}$ HEPES, $16.5 \mathrm{mM}$ $\mathrm{MgCl}_{2}, 82.5 \mathrm{mM} \mathrm{KCl}, 13.2 \mathrm{mM}$ DTT, $6.6 \mathrm{mM}$ ADP, $0.2 \mathrm{mM} \mathrm{NAD}{ }^{+}, 0.7 \mathrm{mM}$ EDTA and $1.2 \mathrm{mM}$ L-carnitine. Two hundred and fifty $\mu \mathrm{L}$ of assay medium was added to a microfuge tube and 10 $\mu \mathrm{L}$ of $\left[1-{ }^{14} \mathrm{C}\right]$ palmitoyl-CoA $(0.3 \mu \mathrm{Ci}, 12 \mu \mathrm{M}$ final conc.) added before incubating the reaction mixture at $20{ }^{\circ} \mathrm{C}$ for $2 \mathrm{~min}$. The reaction was initiated by the addition of $300 \mu \mathrm{L}$ of post-nuclear homogenate (liver and red muscle homogenates were diluted 1:10), and incubation continued at $20{ }^{\circ} \mathrm{C}$ for $10 \mathrm{~min}$. The reaction was stopped by the addition of $150 \mu \mathrm{L}$ of $1.5 \mathrm{M} \mathrm{KOH}$ followed by the addition of $25 \mu \mathrm{L}$ of FAF-BSA $(100 \mathrm{mg} / \mathrm{ml})$. After mixing, $500 \mu \mathrm{Lof}$ ice-cold $4 \mathrm{M} \mathrm{HClO}_{4}$ was added, the mixture vortexed, and centrifuged at $1880 \mathrm{~g}$ for $15 \mathrm{~min}$. Radioactivity in acid soluble products was determined in aliquots of $500 \mu \mathrm{L}$ as described above.

\section{Materials}

[1- $\left.{ }^{14} \mathrm{C}\right]$ Palmitoyl CoA (50-55 mCi/mmol) and [methyl- $\left.{ }^{3} \mathrm{H}\right]$ L-carnitine (60-86 Ci/mmol) were obtained from Amersham Biosciences (Little Chalfont, Bucks, U.K.). BHT, Carnitine, coenzyme A, DTT, FAF-BSA, glutathione, HEPES, KCN, malate, N-acetylcysteine, NADH, NADP, nicotinamide, palmitoyl-CoA, perchloric acid, silver nitrate and TriReagent were obtained from Sigma Chemical Co. (Poole, U.K.). HPTLC (10 cm x $10 \mathrm{~cm} \mathrm{x} 0.15 \mathrm{~mm}$ ) and TLC (20 cm x $20 \mathrm{~cm}$ x $0.25 \mathrm{~mm}$ ) plates, precoated with silica gel 60 (without fluorescent indicator) 


\section{Table 2}

Effect of dietary conjugated linoleic acid (CLA) on growth and biometric parameters of Atlantic salmon \$almo salar )

\begin{tabular}{lccc}
\hline & Fish oil & $2 \%$ CLA & $4 \%$ CLA \\
\hline Initial weight (g) & $132.0 \pm 12.3$ & $131.8 \pm 12.2$ & $132.4 \pm 12.4$ \\
Final weight (g) & $434.5 \pm 64.1^{\text {a }}$ & $434.8 \pm 65.4^{a}$ & $412.2 \pm 53.7^{\mathrm{b}}$ \\
SGR & 1.03 & 1.03 & 0.98 \\
SGR (Pit-tags) & $1.09 \pm 0.14$ & $1.08 \pm 0.11$ & $1.04 \pm 0.08$ \\
FCR & 0.72 & 0.75 & 0.74 \\
VSI & & & \\
HSI & $8.60 \pm 0.70$ & $8.98 \pm 0.57$ & $9.27 \pm 0.98$ \\
CF initial & $1.19 \pm 0.14$ & $1.22 \pm 0.16$ & $1.20 \pm 0.13$ \\
CF final & $1.05 \pm 0.07$ & $1.08 \pm 0.06$ & $1.07 \pm 0.05$ \\
& $1.24 \pm 0.11$ & $1.24 \pm 0.08$ & $1.20 \pm 0.08$ \\
\hline
\end{tabular}

Initial and final weights $(n=250)$, SGR (pit-tags) $(n=20)$, VSI $(n=12)$, HSI $(n=12)$ and CF $(n=12)$ are all means \pm SD. Significance of differences between means were determined by one -way ANOVA folowed by Tukey's multiple comparison post hoc test as described in the Materials and Methods. Values within a row with a different superscript letter are significantly different $(\mathrm{P}<0.05)$.

$\mathrm{CF}$, condition factor $=100 \times$ [(body weight $(\mathrm{g}) /$ body length $(\mathrm{cm})]$ FCR, feed conversion ratio $=$ feed consumed $(\mathrm{kg}) /$ weight gain $(\mathrm{kg})$; HSI, hepato-somatic index $=100 \mathrm{x}$ (liver weight $\mathrm{x}$ body weight; SGR, specific growth rate $(\% /$ day $)=100 \times\left[\left(\ln\right.\right.$ weightal $-\ln$ weight $\left._{\text {nitial }}\right) \mathrm{x}$ days $\left.^{-1}\right]$;

VSI, viscero-somatic index $=100 \mathrm{x}$ (carcass weight $\mathrm{x}$ body weight).

were obtained from Merck (Darmstadt, Germany). All solvents were HPLC grade and were obtained from Fisher Scientific UK, Loughborough, England.

\section{Statistical analysis}

Unless otherwise stated, all data are presented as means \pm SD (n value as stated). The effects of dietary treatment were determined by Students t-test or one-way analysis of variance (ANOVA) followed, where appropriate, by Tukey's comparison test. Percentage data and data which were identified as non-homogeneous (Bartlett's test) were subjected to arcsine transformation before analysis. Differences were regarded as significant when $\mathrm{P}<0.05$.

\section{Results}

Growth and biometry 
The fish fed the 4\% CLA diet showed lower final weights compared to fish fed 2\% CLA and fish fed FO alone (Table 2). However, the specific growth rate (SGR) for individually pit-tagged fish fed 4\% CLA did not differ from the other groups. Dietary CLA had no effect on condition factor, feed efficiency as measured by feed conversion ratio (FCR), hepato-somatic (HSI) or viscero-somatic indices (VSI) (Table 2).

Table 3

Effect of dietary conjugated linoleic acid (CLA) on proximate

composition (percentage) and tissue total lipid content (percentage of wet tissue weight) of Atlantic salmon \$almo salar )

\begin{tabular}{|c|c|c|c|}
\hline Diet & Fish oil & $2 \%$ CLA & $4 \%$ CLA \\
\hline \multicolumn{4}{|l|}{ Proximate } \\
\hline Moisture & $65.5 \pm 0.8$ & $67.1 \pm 0.6 \quad a$ & $67.0 \pm 0.4$ ab \\
\hline Protein & $51.0 \pm 0.5$ & $53.0 \pm 1.3 \mathrm{ab}$ & $53.5 \pm 0.3$ \\
\hline Lipid & $40.5 \pm 0.2$ & $39.7 \pm 1.4$ ab & $38.3 \pm 0.3$ \\
\hline Ash & $5.7 \pm 0.1$ & $5.8 \pm 0.2$ & $6.0 \pm 0.1$ \\
\hline Protein:lipid ratio & $1.28 \pm 0.02$ & $1.40 \pm 0.09 \mathrm{ab}$ & $1.40 \pm 0.00^{a}$ \\
\hline \multicolumn{4}{|l|}{ Tissue lipid } \\
\hline Liver & $4.18 \pm 0.23^{a}$ & $3.45 \pm 0.12^{\mathrm{b}}$ & $3.87 \pm 0.32$ ab \\
\hline Flesh & $8.16 \pm 0.52$ & $7.08 \pm 0.42$ & $7.52 \pm 0.84$ \\
\hline
\end{tabular}

Values are means $\pm S D$ ( $n=3$ whole fish for proximates and 4 samples of tissue each pooled from 3 fish for tissue lipid contents). Significance of differences between means were determined by one-way ANOVA followed, where appropriate, by Tukey's multiple comparison post hoc test as described in the Materials and methods. Values within a row with a different superscript letter are significantly different $(\mathrm{P}<0.05)$.

\section{Proximate, lipid and fatty acid compositions}

Dietary CLA reduced the relative percentage of lipid in the whole fish compared to fish fed the FO diet in the case of fish fed 4\% CLA (Table 3). The relative proportion of protein and the protein:lipid ratio in whole fish were also increased by dietary CLA, particularly at an inclusion level of $4 \%$. Liver total lipid content was reduced by dietary CLA with the level in fish fed $2 \%$ CLA being lower than in fish fed FO (Table 3). The lower level of liver lipid was reflected in the lipid class composition of liver with reduced levels of triacylglycerol (TAG) and total neutral lipid in the livers of fish fed the diets containing CLA compared to fish fed FO alone (Table 4). There were few significant effects of CLA on the lipid class composition of muscle (Table 4). The liver and muscle of fish fed the FO diet were characterised by high levels of 16:0, 20:5n-3 (eicosapentaenoic acid; EPA) and 22:6n-3 (docosahexaenoic acid; DHA), with 20:4n-6 (arachidonic acid; AA) as the major n-6 fatty acid (Table 5). Dietary CLA resulted in the 
Table 4

Effect of dietary conjugated linoleic acid (CLA) on lipid class composition (percentage of total lipid) of liver and flesh of Atlantic salmon (Salmo salar )

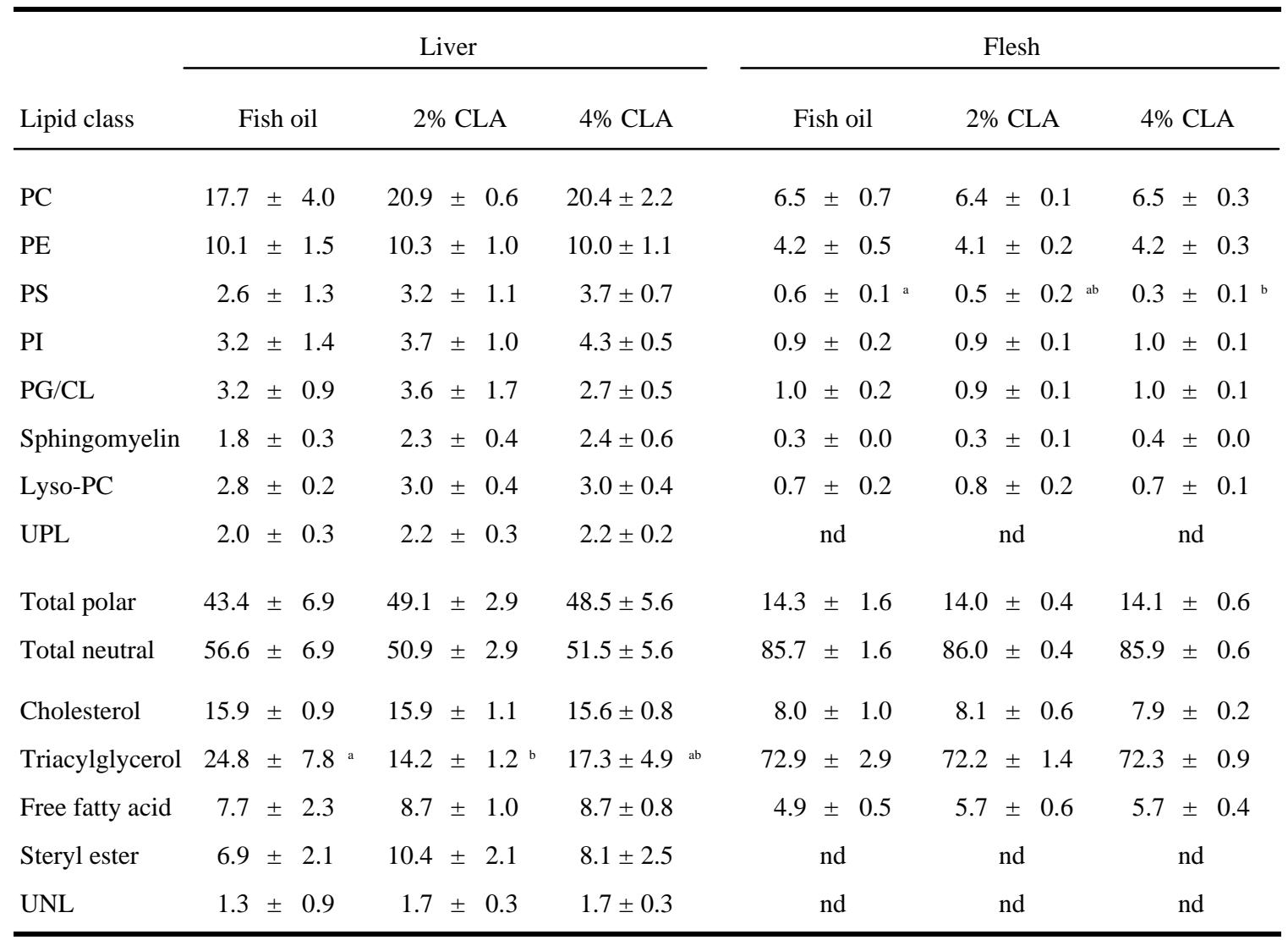

Values are means \pm SD of 4 samples each of tissue pooled from 3 fish. Significance of differences between means for a tissue were determined by one-way ANOVA followed by Tukey's multiple comparison test as described in the Materials Methods. Values within a row for a specific tissue with a different superscript letter are significantly different $(\mathrm{P}<0.05)$ CL, cardiolipin; nd, none detected; PC, phosphatidylcholine; PE, phosphatidylethanolamine; PG, phosphatidylglycerol; PI, phosphatidylinositol; PS, phosphatidylserine; UNL, unknown neutral lipid; UPL, unknown polar lipid.

deposition of CLA in both the liver and the muscle with the accumulation being 2-3-fold higher in the muscle (Table 5). In liver, CLA deposition was accompanied by decreased levels of most monoenes and also 14:0 and 16:0, although 18:0 was increased. In contrast, CLA deposition in the muscle was also accompanied by decreased percentages of n-3 PUFA, whereas the relative proportions of n-3 PUFA in liver were unaffected by dietary CLA (Table 5). Expressing the liver data as fatty acid per unit of total lipid indicated an increase in the amount of AA, EPA and DHA in liver total lipid in fish fed CLA, but expressing the data as fatty acid per unit mass of liver tissue showed no effect of dietary CLA on liver content of these HUFA (Table 6).

\section{Gene expression in liver and intestine}

The major sites of HUFA biosynthesis and desaturase and elongase expression in salmon are liver and intestine (Zheng et al., 2005). These tissues were chosen to test whether CLA affected 
Table 5

Effect of dietary conjugated linoleic acid (CLA) on fatty acid composition (percentage of total fatty acids by weight) of liver and flesh of Atlantic salmon (Salmo salar)

\begin{tabular}{|c|c|c|c|c|c|c|c|}
\hline \multirow[b]{2}{*}{ Fatty acid } & \multicolumn{2}{|l|}{ Liver } & \multicolumn{4}{|c|}{ Flesh } & \multirow[b]{2}{*}{ 4\% CLA } \\
\hline & Fish oil & $2 \%$ CLA & $4 \%$ CLA & & Fish oil & $2 \%$ CLA & \\
\hline 14:0 & $2.7 \unlhd 0.4^{\mathrm{a}}$ & $2.1 \pm 0.1^{b}$ & $2.2 \pm 0.3$ & $\mathrm{~b}$ & $5.4 \pm 0.1^{a}$ & $4.9 \pm 0.1^{b}$ & $4.5 \pm 0.1^{c}$ \\
\hline 16:0 & $16.7 \unlhd 0.8^{\text {a }}$ & $15.1 \pm 0.2^{a b}$ & $14.8 \pm 0.4$ & $\mathrm{~b}$ & $15.3 \pm 0.2^{\mathrm{a}}$ & $14.3 \pm 0.2^{\mathrm{b}}$ & $13.8 \pm 0.2^{b}$ \\
\hline 18:0 & $5.9 \pm 0.4^{c}$ & $8.1 \pm 0.1^{a}$ & $7.4 \pm 0.2$ & $\mathrm{~b}$ & $3.4 \pm 0.2$ & $3.8 \pm 0.1$ & $3.6 \pm 0.1$ \\
\hline Total saturated $^{1}$ & $25.8 \unlhd 0.5$ & $25.8 \pm 0.3$ & $24.9 \pm 0.4$ & & $24.8 \pm 0.4^{\mathrm{a}}$ & $23.7 \pm 0.3^{\mathrm{b}}$ & $22.7 \pm 0.3$ \\
\hline $16: 1^{2}$ & $3.7 \pm 0.6^{\mathrm{a}}$ & $2.6 \pm 0.1^{\mathrm{b}}$ & $2.8 \pm 0.3$ & $\mathrm{~b}$ & $7.1 \pm 0.1^{a}$ & $6.4 \pm 0.1^{\mathrm{b}}$ & $5.8 \pm 0.2^{c}$ \\
\hline $18: 1 n-9$ & $9.3 \pm 1.1^{\mathrm{a}}$ & $6.8 \pm 0.4^{b}$ & $6.8 \pm 0.6$ & $\mathrm{~b}$ & $11.0 \pm 0.3$ & $10.9 \pm 0.1$ & $11.3 \pm 0.1$ \\
\hline 18:1n-7 & $2.9 \pm 0.1$ & $2.8 \pm 0.0$ & $2.7 \pm 0.1$ & & $3.2 \pm 0.0$ & $3.2 \pm 0.0$ & $3.0 \pm 0.1$ \\
\hline $20: 1^{3}$ & $2.5 \pm 0.4$ & $2.0 \pm 0.1$ & $2.2 \pm 0.2$ & & $3.9 \pm 0.1^{a}$ & $3.6 \pm 0.1^{\mathrm{b}}$ & $4.1 \pm 0.1^{a}$ \\
\hline $22: 1^{4}$ & $1.0 \unlhd 0.4^{\mathrm{a}}$ & $0.5 \pm 0.1^{\mathrm{b}}$ & $0.6 \pm 0.2$ & $\mathrm{ab}$ & $3.4 \pm 0.1^{\mathrm{a}}$ & $2.6 \pm 0.1^{\mathrm{b}}$ & $2.9 \pm 0.1$ \\
\hline $24: 1 n-9$ & $1.0 \unlhd 0.1$ & $1.0 \pm 0.1$ & $0.8 \pm 0.1$ & & $0.7 \pm 0.0$ & $0.6 \pm 0.1$ & $0.6 \pm 0.1$ \\
\hline Total mc & $20.3 \pm 2.6^{\mathrm{a}}$ & $15.7 \pm 0.2^{b}$ & $16.0 \pm 1.5$ & $\mathrm{~b}$ & $29.3 \pm 0.4^{\mathrm{a}}$ & $27.5 \pm 0.4^{\mathrm{b}}$ & $27.6 \pm 0.7$ \\
\hline $18: 2 n-6$ & $1.9 \pm 0.4$ & $2.3 \pm 0.9$ & $1.8 \pm 0.3$ & & $3.9 \pm 0.1$ & $4.1 \pm 0.5$ & $3.6 \pm 0.1$ \\
\hline CLA (9c,11t) & $0.0 \pm 0.0^{\mathrm{c}}$ & $0.6 \pm 0.2^{\mathrm{b}}$ & $2.0 \pm 0.2$ & $\mathrm{a}$ & $0.0 \pm 0.0^{\mathrm{c}}$ & $1.9 \pm 0.1^{\mathrm{b}}$ & $4.3 \pm 0.4^{\mathrm{a}}$ \\
\hline CLA $(10 t, 12 c)$ & $0.0 \pm 0.0^{c}$ & $0.5 \pm 0.2^{\mathrm{b}}$ & $2.1 \pm 0.1$ & a & $0.0 \pm 0.0^{c}$ & $1.8 \pm 0.2^{\mathrm{b}}$ & $4.1 \pm 0.5^{\mathrm{a}}$ \\
\hline 20:2n-6 & $0.5 \pm 0.0$ & $0.6 \pm 0.1$ & $0.5 \pm 0.0$ & & $0.4 \pm 0.0$ & $0.4 \pm 0.1$ & $0.4 \pm 0.1$ \\
\hline 20:3n-6 & $0.3 \pm 0.1$ & $0.3 \pm 0.1$ & $0.3 \pm 0.1$ & & $0.2 \pm 0.0$ & $0.2 \pm 0.0$ & $0.2 \pm 0.0$ \\
\hline $20: 4 n-6$ & $2.8 \pm 0.4$ & $3.3 \pm 0.1$ & $3.1 \pm 0.2$ & & $0.8 \pm 0.1$ & $0.8 \pm 0.0$ & $0.7 \pm 0.0$ \\
\hline Total n-6 PUFA ${ }^{5}$ & $6.4=0.1$ c & $8.5 \pm 1.1^{b}$ & $10.6 \pm 0.2$ & a & $6.0 \pm 0.1^{c}$ & $10.0 \pm 0.5^{b}$ & $13.9 \pm 0.9^{\mathrm{a}}$ \\
\hline $18: 3 n-3$ & $0.6=0.2$ & $0.5 \pm 0.1$ & $0.5 \pm 0.1$ & & $1.3 \pm 0.0$ & $1.2 \pm 0.1$ & $1.4 \pm 0.3$ \\
\hline $18: 4 n-3$ & $0.6 \pm 0.3$ & $0.4 \pm 0.2$ & $0.4 \pm 0.2$ & & $2.3 \pm 0.1^{\mathrm{a}}$ & $2.0 \pm 0.1 \mathrm{ab}$ & $1.8 \pm 0.1^{b}$ \\
\hline 20:3n-3 & $0.2 \pm 0.1$ & $0.2 \pm 0.1$ & $0.1 \pm 0.0$ & & $0.2 \pm 0.1$ & $0.2 \pm 0.1$ & $0.2 \pm 0.1$ \\
\hline $20: 4 n-3$ & $1.2=0.3$ & $1.3 \pm 0.1$ & $1.4 \pm 0.1$ & & $1.8 \pm 0.0$ & $1.7 \pm 0.1$ & $1.7 \pm 0.1$ \\
\hline $20: 5 n-3$ & $10.7 \unlhd 0.3$ & $11.1 \pm 0.4$ & $10.8 \pm 0.1$ & & $10.8 \pm 0.3^{a}$ & $10.2 \pm 0.2^{\mathrm{b}}$ & $9.3 \pm 0.3^{c}$ \\
\hline $22: 5 n-3$ & $3.6 \pm 0.0$ & $3.8 \pm 0.1$ & $3.6 \pm 0.1$ & & $3.5 \pm 0.0^{\mathrm{a}}$ & $3.5 \pm 0.1^{\mathrm{a}}$ & $3.1 \pm 0.1^{b}$ \\
\hline $22: 6 n-3$ & $30.0 \unlhd 2.7$ & $32.3 \pm 0.6$ & $31.2 \pm 2.0$ & & $18.2 \pm 0.3^{a}$ & $18.2 \pm 0.4^{\mathrm{a}}$ & $16.8 \pm 0.2$ \\
\hline Total n-3 PUFA & $46.9 \pm 2.2$ & $49.5 \pm 1.1$ & $48.0 \pm 1.8$ & & $38.1 \pm 0.5^{a}$ & $37.1 \pm 0.6^{\mathrm{a}}$ & $34.4 \pm 0.1$ \\
\hline Total PUFA & $54.0 \unlhd 2.2^{b}$ & $58.5 \pm 0.3^{a}$ & $59.0 \pm 1.7$ & 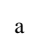 & $45.9 \pm 0.5^{b}$ & $48.8 \pm 0.5^{\mathrm{a}}$ & $49.8 \pm 1.0$ \\
\hline
\end{tabular}

Values are means \pm SD of 4 samples each of tissue pooled from 3 fish. Significance of differences between means for a tissue were determined by one-way ANOVA followed by Tukey's multiple comparison post hoc test as described in the Materials and Methods. Values within a row for a specific tissue with a different superscript letter are significantly different $(\mathrm{P}<0.05)$. 1 , contains $15: 0,20: 0$ and $22: 0$, present at up to $0.3 \%$; 2 , predominantly n-7 isomer; 3, predominantly n-9 isomer; 4, predominantly n-11 isomer; 5 , totals include $18: 3 n-6,22: 4 n-6$ and 22:5n-6 present at up to $0.3 \%$; PUFA, polyunsaturated fatty acid.

fatty acyl $\Delta 6$ desaturase or elongase gene expression. In addition the mRNA levels of known salmon PPAR isotypes, ie PPAR $\alpha$, PPAR $\gamma$ and two isoforms of PPAR $\beta$ and of CPT1 were measured (Fig 1). Dietary CLA generally had no effect on the expression of PPAR genes compared to FO alone, either in liver or in intestine with the exception of PPAR $\beta 2$ that showed reduced expression in liver at the higher CLA inclusion level. CPT1 expression was increased at 
the higher inclusion level in liver. Fatty acid $\Delta 6$ desaturase mRNA was not changed in either liver or intestine, and the levels of this transcript showed more inter-individual variability than the other genes measured. In contrast, in both liver and intestine, fatty acid elongase expression was increased at both levels of dietary CLA.

Table 6

Effect of conjugated linoleic acid (CLA) on fatty acid content of livers of Atlantic salmon (Salmo salar )

\begin{tabular}{|c|c|c|c|c|}
\hline & Fish Oil & $2 \%$ CLA & $4 \%$ CLA & \\
\hline \multicolumn{5}{|c|}{$\underline{\text { mg fatty acid/g total lipid }}$} \\
\hline $20: 4 n-6$ & $13.9 \pm 1.0$ & $18.1 \pm 1.2$ & $16.5 \pm 1.0$ & a \\
\hline $20: 5 n-3$ & $53.7 \pm 4.4$ & $61.4 \pm 1.4$ & $57.0 \pm 0.6$ & ab \\
\hline $22: 6 n-3$ & $149.1 \pm 7.3$ & $178.8 \pm 7.3$ & $164.4 \pm 8.2$ & a \\
\hline Total n-3 PUFA & $233.9 \pm 14.4^{b}$ & $273.7 \pm 10.9^{\mathrm{a}}$ & $252.8 \pm 6.0$ & ab \\
\hline Total PUFA & $269.1 \pm 18.0^{b}$ & $324.1 \pm 18.8^{a}$ & $311.1 \pm 4.7$ & a \\
\hline \multicolumn{5}{|c|}{$\underline{\text { mg fatty acid/g liver wet weight }}$} \\
\hline $20: 4 n-6$ & $0.58 \pm 0.04$ & $0.62 \pm 0.04$ & $0.64 \pm 0.04$ & \\
\hline $20: 5 n-3$ & $2.24 \pm 0.18$ & $2.12 \pm 0.05$ & $2.21 \pm 0.03$ & \\
\hline $22: 6 n-3$ & $6.23 \pm 0.31$ & $6.17 \pm 0.25$ & $6.38 \pm 0.32$ & \\
\hline Total n-3 PUFA & $9.78 \pm 0.60$ & $9.44 \pm 0.37$ & $9.81 \pm 0.23$ & \\
\hline Total PUFA & $11.25 \pm 0.75$ & $11.18 \pm 0.65$ & $12.07 \pm 0.18$ & \\
\hline
\end{tabular}

Values are means \pm SD of 4 samples each of tissue pooled from 3 fish.

Significance of differences between means were determined by one-way ANOVA followed, where appropriate, by Tukey's multiple comparison post hoc test as described in the Materials and Methods. Values within a row with a different superscript letter are significantly different $(\mathrm{P}<0.05)$. PUFA, polyunsaturated fatty acid.

\section{Liver and muscle lipid metabolic activities}

In view of the observed changes in CPT1 and elongase expression associated with significant differences in liver lipid composition after CLA feeding, a variety of enzymic activities relating to lipid metabolism were measured in liver, and red and white muscle. Liver $\beta$-oxidation activity was increased by dietary CLA, but no effect of CLA was detected on the activity of liver CPT1 (Fig.2). In contrast, in red muscle CLA feeding appeared to reduce $\beta$-oxidation activity and this was reflected in a slight reduction in CPT1 activity. Dietary CLA at the higher inclusion level resulted in a rise in HUFA synthesis in liver microsomes. Levels of liver malic enzyme activity, an indicator of fatty acid biosynthetic capacity were unaffected by CLA feeding (Fig.2). No significant effects on any of the parameters were observed in white muscle. 
A

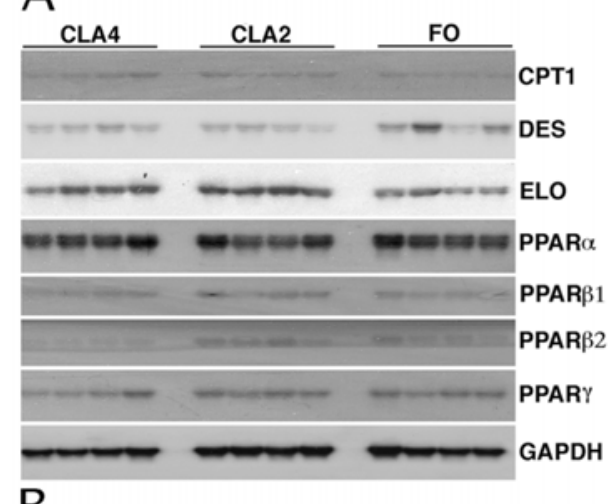

B

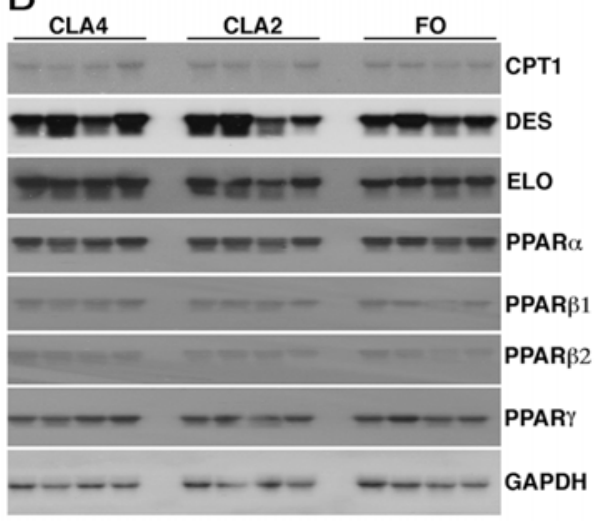

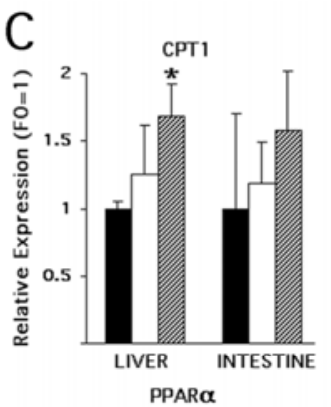
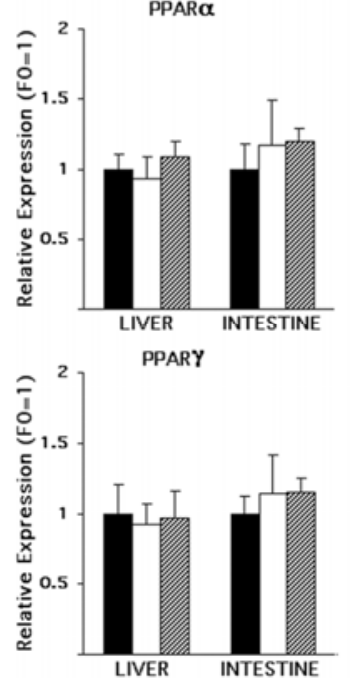
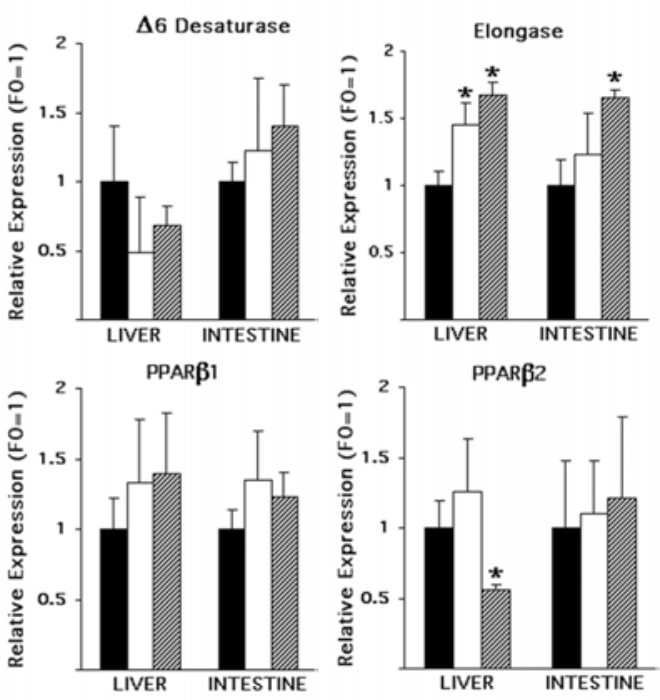

Fig.1. Effects of the diets on gene expression in liver and intestine.

The expression of PPAR $\alpha, \beta 1, \beta 2, \gamma, \Delta 6$ desaturase (des), elongase (elo), GAPDH and CPT1 genes were determined by semi-quantitative Northern blotting of liver and intestine total RNA as described in the Materials and Methods section. Panel A: Northern blots of liver RNA of four individuals from each dietary treatment. Panel B: Northern blots of intestine RNA of four individuals from each dietary treatment. Panel C: Results of densitometrically scanned blots, results expressed relative to fish oil and after normalisation to GAPDH; Error bars represent standard deviations of result from four fish from each treatment and asterisks indicate a significant difference $(\mathrm{P}<0.05$; Students t-test) from fish oil treatment.

\section{Discussion}

This salmon study involved feeding the two major CLA isomers cis 9, trans 11 CLA and trans 10, cis 12 CLA in equal amounts as free fatty acids. In mammals feeding of CLA has varying effects, depending on the species, tissue and on the relative amounts of specific CLA isomers. Thus in mice the trans 10, cis 12 isomer has dramatic effects, including a reduction in body fat mass (Wang and Jones, 2004), increases in hepatic18:1n-9 and apparent increases in liver $\beta$-oxidation (Degrace et al, 2004; Javadi et al, 2004). Whilst the cis 9, trans 11 isomer has lesser, but qualitatively similar effects on fat distribution, it differs from the trans 10, cis 12 isomer in producing a decrease in hepatic 18:1n-9 (Kelley et al, 2004). Feeding of the trans 10, cis 12 isomer in mice also induces adverse effects such as increased insulin resistance and large increases in liver weight, triacylglycerols and cholesterol (Wang and Jones, 2004; Kelley et al., 2004). In other species such as pigs (Sus scofa) and humans (Homo sapiens) after trans 10, cis 12 feeding, although there is evidence of body fat loss, there are no clear data for other biochemical parameters (Wang and Jones, 2004). Similar to hamster, the present study shows a marked decrease in salmon liver triacylglycerol associated with a general decrease in total body lipid after CLA feeding. Previous studies feeding Atlantic salmon CLA (Berge et al 2004; Kennedy et al., 2005) did not demonstrate any gross effects on growth, although, similar to this study, a 

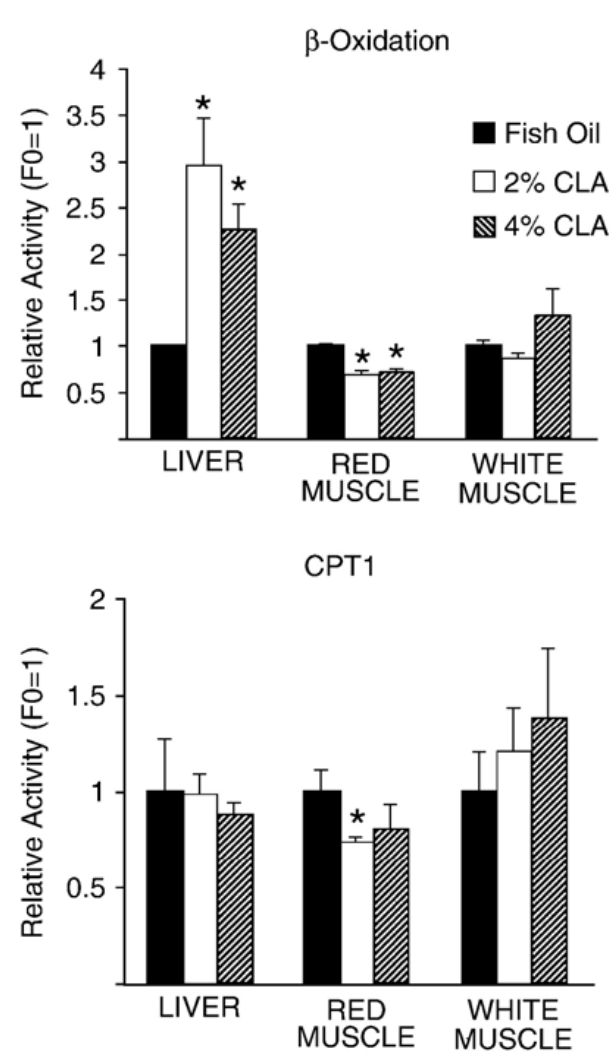
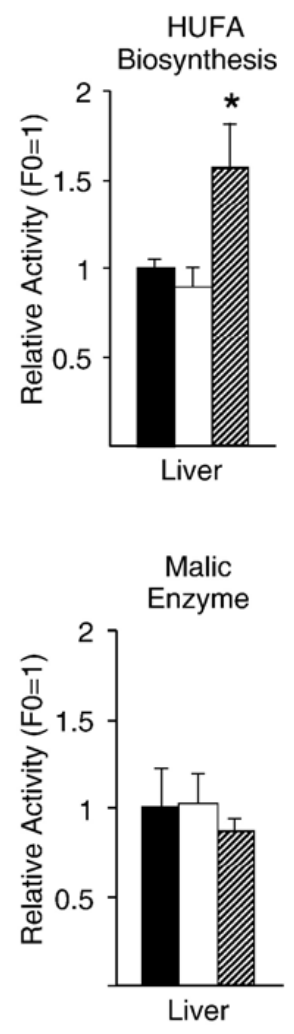

Fig.2. Effects of diets on metabolic parameters in the liver and muscle tissues. Total $\beta$-oxidation activity, the activity of carnitine palmitoyl-tranferase 1 (CPT1), and malic enzyme activity were determined in tissue homogenates. HUFA biosynthetic capacity was determined in liver microsome preparations. Error bars represent standard deviations of result from five fish from each treatment and asterisks indicate a significant difference ( $\mathrm{P}<0.05$; Students t-test) from fish oil treatment.

general increase in polyunsaturated fatty acids and a decrease in monounsaturated 16:1n-7 and 18:1n-9 was observed. Similarly, studies on yellow perch (Perca flavescens) and hybrid striped bass (Morone saxatilis $x$ M. chrysops) have demonstrated reduced liver lipid after CLA feeding and similar to salmon, increased 18:0 and decreased monounsaturated fatty acids (Twibell et al., 2000, 2001). In mammals, these effects on specific fatty acids have been suggested to be due to suppression or direct inhibition of stearoyl CoA $(\Delta 9$ ) desaturase (SCD) (Choi et al.,2002a, 2002b; Eder 2002). Whilst this mechanism could also occur in salmon, the significant increase in 18:0 and decrease in both 14:0 and 16:0 might also be explained by the observed increase in elongase mRNA expression, which, against a possible background of reduced SCD activity, leads to accumulation of 18:0. Salmon liver HUFA biosynthesis was also increased and there were apparent increases in levels of HUFA (AA, EPA and DHA) in salmon liver when expressed per unit total lipid. Previous studies have noted similar increases in the relative proportion of HUFA in fish liver (Twibell et al., 2001; 2000), and decreases in muscle after CLA feeding in fish (Kennedy et al., 2005). This increase in salmon liver HUFA synthesis cannot be explained by changes in $\Delta 6$ desaturase mRNA which were quite variable between individuals and not significantly altered by CLA feeding. In mammals, conflicting data exist regarding CLA effects on $\Delta 5$ and $\Delta 6$ desaturases, the rate limiting enzymes of HUFA biosynthesis. Some studies indicate suppression after CLA feeding (Eder et al, 2002), while others show marked induction (Takahashi et al, 2003; Peters et al 2001). However, it is possible that the increase in HUFA biosynthesis might be explained by the increase in elongase mRNA in CLA fed salmon, although we have no evidence to equate gene expression levels with enzyme activities. Perhaps the most marked difference in CLA fed salmon was the large increase in liver $\beta$-oxidation, an effect also generally observed in rodents. This was not accompanied by increases in liver CPT1 activity, although increased liver CPT1 mRNA expression was observed. This increase in $\beta$-oxidation in liver was accompanied by decreased $\beta$-oxidation capacity and decreased CPT1 mRNA in red 
muscle. It should be noted that in Atlantic salmon of the age and size used here, peroxisomal $\beta$ oxidation has been shown to account for the vast majority of activity in liver whilst the tissue with the highest $\beta$-oxidation capacity is red muscle where mitochondrial activity predominates (Froyland et al., 2000). Thus it is possible that the effect of CLA is to switch from mitochondrial $\beta$-oxidation in red muscle, as indicated by the reduction in $\beta$-oxidation and CPT1 activity, to peroxisomal $\beta$-oxidation in liver as indicated by the large increase in $\beta$-oxidation without concomitant increases in CPT1 activity. In contrast to $\beta$-oxidation and HUFA biosynthesis, there was no evidence of increased lipogenic activity in livers of CLA fed salmon as shown by the lack of response of malic enzyme and the reduction in triacylglycerol. This is similar to observations in rainbow trout where feeding of CLA up to $2 \%$ of diet did not change the activities of a variety of lipogenic enzymes (Figueiredo-Silva et al., 2005). This lack of effect of CLA on lipogenesis is also apparent in hamster where feeding of trans 10, cis 12 CLA reduces hepatic triacylglycerol and lipogenesis remains unaffected (Zabala et al, 2004), although, in mice CLA increases lipogenic activity and this has been suggested, at least in part, as an explanation for increased hepatic triacylglycerol seen in the liver in this species, despite increased $\beta$-oxidation capacity (Javadi et al., 2004). The underlying mechanisms for the effects of CLA on lipid metabolism are unclear. One mechanism has been postulated to be via activation of PPARs (Moya-Camarena et al., 1999). PPARs are ligand-dependent transcription factors that are known to have critical roles in regulating lipid homeostasis in a variety of tissues, principally liver, muscle and adipose. These proteins act by regulating the activity of numerous genes involved in fatty acid storage, uptake and metabolism. (Desvergne and Wahli, 1999). Studies on PPAR $\alpha$-null mice have shown that the most of the effects of CLA on genes involved in mitochondrial $\beta$-oxidation are independent of PPAR $\alpha$, whilst a marker of peroxisomal $\beta$-oxidation, acyl-CoA oxidase, was increased by CLA via a PPAR $\alpha$-dependent mechanism (Peters et al, 2001). CLA has been shown to be an effective activating ligand for piscine PPAR $\alpha$, with only small effects on PPAR $\beta$ and no effects on PPAR $\gamma$ (Leaver et al, 2005). PPAR $\alpha$, the predominant PPAR isotype expressed in vertebrate liver, PPAR $\gamma$ and PPAR $\beta$ mRNAs were all expressed in salmon liver and unaffected by CLA feeding, suggesting that PPAR regulatory pathways would be functional. Taken together the results for salmon are consistent with CLA causing an increase in liver peroxisomal $\beta$-oxidation, possibly via a PPAR-dependent mechanism. This induction of peroxisomal $\beta$ oxidation may be a mechanism for metabolising CLA, as is the case with other atypical fatty acids, such as branched chain or very long chain molecules which are structurally incapable of undergoing mitochondrial metabolism (Reddy and Mannaerts, 1994; Singh et al, 1994). If true this might suggest that CLA was effectively exerting a toxic effect on salmon. This together with the small negative effects on overall growth, the slight increases in HUFA and decreases in total lipid, leads to the conclusion that dietary CLA would exert only marginal benefits from a salmon farmers point of view.

\section{Acknowledgements}

This work and MJL were supported by the European Union (Cloning and functional analysis of fish peroxisome proliferator-activated receptors: the transcriptional control of lipid metabolism in farmed fish species (fPPARs)”, Q5RS-2000-30360) as part of the Fifth Framework Quality of Life Programme.

\section{References}


Ackman, R.G., 1980. Fish lipids, part 1. In: Connell (ed), Advances in Fish Science and Technology, Fishing News Books, Farnham, U.K., pp. 87-103.

Bell, G., Torstensen, B., Sargent, J., 2005. Replacement of marine fish oils with vegetable oils in feeds for farmed salmon, Lipid Technol., 17, 7-11.

Belury, M.A, 2002. Dietary conjugated linoleic acid in health: physiological effects and mechanisms of action. Annu. Rev. Nutr., 22, 505-531.

Berge, G.M., Ruyter, B., Asgard, T., 2004. Conjugated linoleic acid in diets for juvenile Atlantic salmon (Salmo salar); effects on fish performance, proximate composition, fatty acid and mineral content, Aquaculture, 237, 365-380.

Bouthegourd, J.C., Even, P.C., Gripois, D., Toffon, B., Blouquit, M.F., Roseau, S., Lutton, C., Tome, D., Martin, J.C., 2002. A CLA mixture prevents body triglyceride accumulation without affecting energy expenditure in Syrian hamsters. J. Nutr., 132, 2682-2689.

Chin, S.F., Liu, W., Storkson, J.M., Ha, Y.L., Pariza, M.W., 1992. Dietary sources of conjugated dienoic isomers of linoleic acid, a newly recognized class of anticarcinogens, J. Food Comp. Anal., 5, 185-197.

Choi, Y., Park, Y., Storkson, J.M., Pariza, M.W., Ntambi, J.M., 2005. Inhibition of stearoyl-CoA desaturase activity by the cis-9,trans-11 isomer and the trans-10,cis-12 isomer of conjugated linoleic acid in MDA-MB-231 and MCF-7 human breast cancer cells, Biochem. Biophys. Res. Commun., 294, 785-790.

Christie, W.W., 1982. Lipid Analysis, 2nd edition. Pergamon Press, Oxford, pp. 207.

Chuang, L.T., Thurmond, J.M., Liu, J.W., Kirchner, S.J., Mukerji, P., Bray, T.M., Huang, Y.S., 2001a. Effect of conjugated linoleic acid on fungal $\Delta 6$-desaturase activity in a transformed yeast system, Lipids, 36, 139- 143.

Chuang, L.T., Leonard, A.E., Liu, J.W., Mukerji, P., Bray, T.M., Huang, Y.S., 2001b. Inhibitory effect of conjugated linoleic acid on linoleic acid elongation in transformed yeast with human elongase, Lipids, 36, 1099-1103.

Clement, L., Poirier, H., Niot, I., Bocher, V., Guerre-Millo, M., Krief, S., Staels, B., Besnard, P., 2002. Dietary trans-10,cis-12 conjugated linoleic acid induces hyperinsulinemia and fatty liver in the mouse, J. Lipid Res., 43, 1400-1409.

Degrace, P., Demizieux, L., Gresti, J., Chardigny, J.M., Sebedio, J.L., Clouet, P., 2004. Hepatic steatosis is not due to impaired fatty acid oxidation capacities in C57BL/6J mice fed the conjugated trans-10,cis-12-isomer of linoleic acid, J. Nutr., 134, 861-867.

Desvergne, B., Wahli, W., 1999. Peroxisome proliferator-activated receptors: nuclear control of metabolism, Endocr. Rev. 20, 649-688.

Eder, K., Slomma, N., Becker, K., 2002. Trans-10,cis-12 conjugated linoleic acid suppresses the desaturation of linoleic and $\alpha$-linolenic acids in HepG2 cells, J. Nutr., 132, 1115-1121. 
Figueiredo-Silva, A.C., Rema, P., Bandarra, N.M., Nunes, M.L., Valente, L.M.P., 2005 Effects of dietary conjugated linoleic acid on growth, nutrient utilization, body composition, and hepatic lipogenesis in rainbow trout juveniles (Oncorhynchus mykiss). Aquaculture, 248, 163-172.

Folch, J., Lees, M. and Sloane-Stanley, G.H. 1957. A simple method for the isolation and purification of total lipids from animal tissues, J. Biol. Chem., 226, 497-509.

Frøyland, L., Lie, Ø., Berge, R.K. 2000. Mitochondrial and peroxisomal beta-oxidation capacities in various tissues from Atlantic salmon Salmo salar, Aquaculture Nutr., 6, 85-89.

Ghioni, C., Tocher, D.R., Sargent, J.R., 1997. The effect of culture on morphology, lipid and fatty acid composition, and polyunsaturated fatty acid metabolism of rainbow trout (Oncorhynchus mykiss) skin cells, Fish Physiol. Biochem., 16, 499-513.

Henderson, R. J., Tocher, D. R., 1992. Thin-layer chromatography. In: Hamilton, R. J., Hamilton, S.(eds.), Lipid Analysis : A Practical Approach, Oxford University Press, Oxford, pp. 65-111.

Javadi, M., Beynen, A.C., Hovenier, R., Lankhorst, A.E., Lemmens, A.G., Terpstra, A.H.M., Geelen, M.J.H., 2004. Prolonged feeding of mice with conjugated linoleic acid increases hepatic fatty acid synthesis relative to oxidation. J. Nutr. Biochem.,15, 680-687.

Kelley, D.S., Bartolini, G.L., Warren, J.M., Simon, V.A., Mackey, B.E., Erickson, K.L., 2004. Contrasting effects of t10,c12-and c9,t11-conjugated linoleic acid isomers on the fatty acid profiles of mouse liver lipids, Lipids, 39,135-141.

Kennedy, S.R., Campbell, P.J, Porter, A., Tocher, D. R., 2005. Influence of dietary conjugated linoleic acid (CLA) on lipid and fatty acid composition in liver and muscle of Atlantic salmon (Salmo salar), Comp. Biochem. Physiol. B, 141, 168-178.

Leaver, M.J., Boukouvala, E., Antonopoulou, E., Diez, A., Favre-Krey, L., Ezaz, M.T., Tocher, D.R., Batista, J.M., Krey, G., 2005. Three peroxisomal proliferator-activated receptor (PPAR) isotypes from each of two species of marine fish. Endocrinology, 146, 3150-3162.

Macarulla, M.T., Fernandez-Quintela, A., Zabala, A., Navarro, V., Echevarria, E., Churruca, I., Rodriguez, V.M., Portillo, M.P.,2005. Effects of conjugated linoleic acid on liver composition and fatty acid oxidation are isomer-dependent in hamster, Nutrition, 21, 512-519.

Moya-Camarena, S.Y., Van den Heuvel, J.P., Belury, M.A., 1999 Conjugated linoleic acid activates peroxisome proliferator-activated receptor $\alpha$ and $\beta$ subtypes but does not induce hepatic peroxisome proliferation in Sprague-Dawley rats. Biochim. Biophys. Acta, 1436, 331-342.

Naylor, R. L. Goldburg, R.J., Primavera, J.H., Kautsky, N., Beveridge, M.C.M., Clay, J., Folke, C., Lubchenco, J., Mooney, H., Troell, M., 2000. Effect of aquaculture on world fish supplies. Nature, 405, 1017 - 1024.

Pariza, M.W., Park, Y., Cook, M.E., 2001. The biologically active isomers of conjugated linoleic acid. Prog. Lipid Res. 40, 283-298. 
Peters ,J.M., Park, Y., Gonzalez, F., Pariza, M.W., 2001. Influence of conjugated linoleic acid on body composition and target gene expression in peroxisome proliferator-activated receptor $\alpha$-null mice, Biochim. Biophys. Acta, 1533, 233-242.

Reddy, J.K., Mannaerts, G.P., 1994. Peroxisomal lipid metabolism, Annu Rev Nutr., 14, 343-70.

Sargent, J.R., Tacon, A. 1999. Development of farmed fish: a nutritionally necessary alternative to meat, Proc. Nutr. Soc., 58, 377-383.

Sargent, J.R., Tocher, D.R., Bell, J.G., 2002. The lipids. In: Halver, J.E. and Hardy, R.W. (eds), Fish Nutrition. Edited by Academic Press, San Diego, pp. 181-257

Singh, H., Beckman, K., Poulos, A., 1994. Peroxisomal beta-oxidation of branched chain fatty acids in rat liver. Evidence that carnitine palmitoyltransferase I prevents transport of branched chain fatty acids into mitochondria, J. Biol. Chem., 269, 9514-9520

Takahashi, Y., Kushiro, M., Shinohara, K., Ide, T., 2003. Activity and mRNA levels of enzymes involved in hepatic fatty acid synthesis and oxidation in mice fed conjugated linoleic acid, Biochim. Biophys. Acta, 1631, 265-273.

Thiel-Cooper, R.L., Parrish, F.C., Sparks, J.C., Weigand, B.R., Ewan, R.C., 2001. Conjugated linoleic acid changes swine performance and carcass composition. J. Anim. Sci. 79, 1821- 1828.

Tocher, D.R., Harvie, D.G., 1988. Fatty acid compositions of the major phosphoglycerides from fish neural tissues : (n-3) and (n-6) polyunsaturated fatty acids in rainbow trout (Salmo gairdneri, L.) and cod (Gadus morhua) brains and retinas, Fish Physiol. Biochem., 5, 229-239.

Torstensen, B.E., Li, Ø. and Frøyland, L,. 2000. Lipid metabolism and tissue composition in Atlantic salmon (Salmo salar L.) - Effects of capelin-, palm- and oleic acid enriched sunflower oil as dietary lipid sources, Lipids, 35, 653-664.

Tsuboyama-Kasaoka, N., Takahashi, M., Tanemura, K., Kim, H.J., Tange, T., Okuyama, H., Kasai, M., Ikemoto, S., Ezaki, O., 2000. Conjugated linoleic acid supplementation reduces adipose tissue by apoptosis and develops lipodystrophy in mice, Diabetes, 4, 1534-1542

Twibell, R.G., Watkins, B.A., Brown, P.B., 2001. Dietary conjugated linoleic acids and lipid source alter fatty acid composition of juvenile yellow perch, Perca flavescens. J. Nutr., 131, 2322- 2328.

Twibell, R.G., Watkins, B.A., Rogers, L., Brown, P.B., 2000. Effects of dietary conjugated linoleic acids on hepatic and muscle lipids in hybrid striped bass, Lipids 35, 155-161.

U.S. National Research Council, 1993. Nutrient requirements of fish, National Academy Press, Washington D.C.

Wang, Y., Jones P.J., 2004, Dietary conjugated linoleic acid and body composition. Am. J. Clin. Nutr., 79, 1153S-1158S 
Wilson, R., Sargent, J.R., 1992. High resolution separation of polyunsaturated fatty acids by argentation thin-layer chromatography, J. Chromatogr., 623, 403-407.

Zabala, A., Churruca, I., Macarulla, M.T., Rodriguez, V.M., Fernandez-Quintela, A., Martinez, J.A., Portillo, M.P. 2004. The trans-10,cis-12 isomer of conjugated linoleic acid reduces hepatic triacylglycerol content without affecting lipogenic enzymes in hamsters, Brit. J. Nutr., 92, 383389.

Zheng, X., Tocher, D.R., Dickson, C., Dick, J.R., Bell, J.G., Teale, A.J., 2005. Highly unsaturated fatty acid synthesis in vertebrates: new insights with the cloning and characterisation of a $\Delta 6$ desaturase of Atlantic salmon, Lipids, 40, 13-24. 